\title{
Rusudan Makhachashvili
}

Habilitated Doctor, Head of Romance Languages and Typology Department

Borys Grinchenko Kyiv University, Kyiv, Ukraine

r.makhachashvili@kubg.edu.ua

ORCID: 0000-0002-4806-6434

\section{Ivan Semenist}

PhD, Head of Oriental Languages and Translation Department

Borys Grinchenko Kyiv University, Kyiv, Ukraine

i.semenist@kubg.edu.ua

ORCID: 0000-0002-0847-8856

\section{Anna Bakhtina}

Assistant Professor, Graduate student

Borys Grinchenko Kyiv University, Kyiv, Ukraine

a.bakhtina@kubg.edu.ua

ORCID: 0000-0003-3337-6648

\section{DIGITAL SKILLS DEVELOPMENT AND ICT TOOLS FOR FINAL QUALIFICATION ASSESSMENT: SURVEY STUDY FOR STUDENTS AND STAFF OF EUROPEAN AND ORIENTAL PHILOLOGY PROGRAMS}

\begin{abstract}
The global pandemic and subsequent quarantine measures and restrictions have posed an array of challenges to the structure and procedure of university summative assessment process. Qualification assessment for Foreign Languages major programs in particular is a strict regimen process that involves different stages (oral and written exams, final project viva, internal and external review). Factors of societal change, that provide the backdrop for skillset critical transformation, crucial for the COVID-19 emergency educational framework are considered. The study premise is based on identification of various competency principles, derivative of 21 st century skills for university staff members and projected digital literacy requirements. A correspondence between 21 st century skills framework, Competences 2020 framework and the newly devised Global Skills framework has been devised. The study objective is to critically review the applied case and best practices of Borys Grinchenko Kyiv University Digital Final Qualification Assessment for students of European (French, Italian, Spanish, English, German) and Oriental (Mandarin Chinese, Japanese) Languages major programs, employed in the year 2020 due to quarantine measures. The survey and analysis of different ICT tools is used to translate real life qualification assessment practices into online blended format. The investigation also seeks to identify various groups of applied digital skills and collaboration skills, utilized through qualification assessment process by all parties (students, faculty and referees). It is determined how in the situation of the COVID-19 pandemic lockdown all elements of the Final Qualification Assessment at Borys Grinchenko Kyiv University for European and Oriental Languages programs have been relegated to the digital, remote or blended format with the use of ICT tools. The qualification assessment regimen for foreign languages major programs was adapted to digital format as a framework (a legal procedure that results in the degree confirmation of a student), the string of consecutive communicative activities according to the legal procedure, the "ritual" scenario. Comparative results of the Final Qualification Assessment digital format adaptation for different groups of foreign languages programs (European and Oriental) are devised.
\end{abstract}

Keywords: ICT Tools and Practices; Final Qualification Assessment; digital literacy; blended learning; survey study; European languages; Oriental languages

Introduction. The global pandemic and subsequent quarantine measures and restrictions have posed an array of challenges to the structure and procedure of university summative assessment process. Qualification assessment for Foreign Languages major programs in particular is a strict regimen process that involves different stages (oral and written exams, final project viva, internal and external review).

This study objective is to critically review the applied case and best practices of Borys Grinchenko Kyiv University Digital Final Qualification Assessment for students of European 
(French, Italian, Spanish, English, German) and Oriental (Mandarin Chinese, Japanese) Languages major programs, employed in the year 2020 due to quarantine measures. The survey and analysis of different ICT tools is used to translate real life qualification assessment practices into online blended format. The investigation also seeks to identify various groups of applied digital skills and collaboration skills, utilized through qualification assessment process by all parties (students, faculty and referees).

The global pandemic of COVID-19 emerged as a black swan scenario for various spheres of social and economic life, including education. The black swan theory is a metaphor that describes an event that comes as a surprise, has a major effect on society, and is often inappropriately rationalized after the fact with the benefit of hindsight (Taleb, 2010).

In the educational sphere, according to our estimations, the result of the COVID-19 pandemic development was the need to take quick action in order to achieve such desirable results:

a) To adapt the existent educational scenarios to digital, remote and blended formats;

b) To boost ICT competence and digital literacy of all participants of the educational process.

Development of digital literacy for Liberal Arts professionals through the latest decade has been governed by the following factors of societal change, overviewed in "Future work skills 2020" (Davies, Fidler, 2011), that can be summarized as follows (Figure 1): extension of life-span; development of smart technologies and robotics; new media literacy modes; computerized and globalized world; extensive social structures.

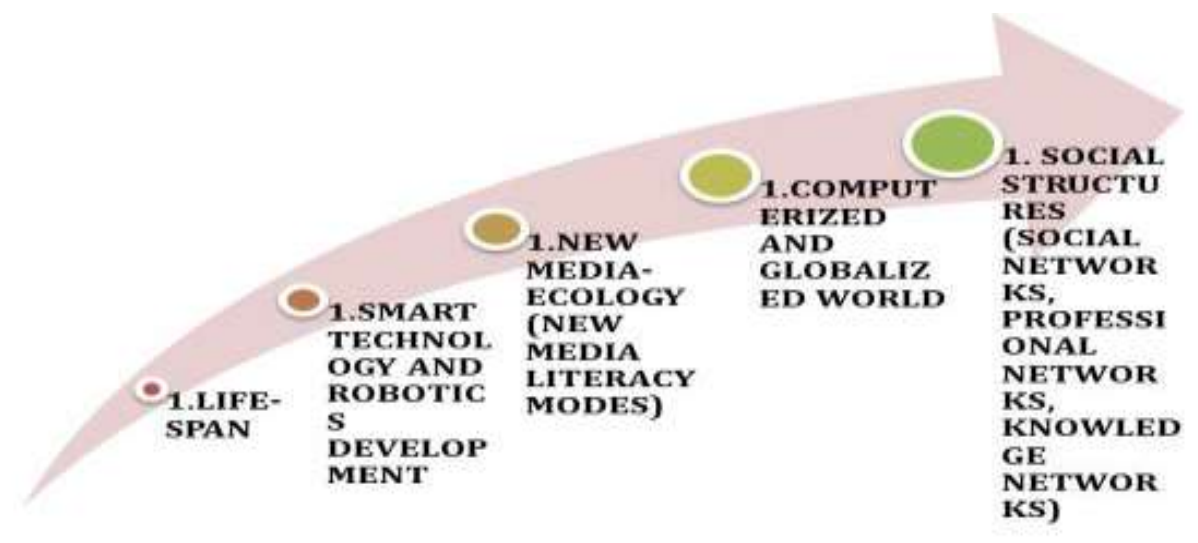

Fig. 1. Factors of societal changes

Source: Own research

The combination of skills of the future to be developed due to the application of the aforementioned social factors takes on the following arrangement (Table 1):

Table 1.

Factors of social change and skills of the future

\begin{tabular}{|c|l|}
\hline FACTORS OF SOCIAL CHANGE: & \multicolumn{1}{|c|}{ SKILLS OF THE FUTURE } \\
\hline Combination 1: & $\square$ Knowledge creation \\
\hline$\square$ life span, & $\square$ Innovative and adaptive thinking \\
$\square$ smart technologies development, & $\square$ Interdisciplinary \\
$\square$ new media ecology & $\square$ Social intellect \\
\hline Combination 2: & $\square$ Cognitive management \\
\hline & $\square$ Makering outlook \\
$\square$ Globalization & $\square$ Intercultural competence \\
$\square$ Extensive social structures & $\square$ Virtual collaboration \\
$\square$ Computerization & \\
\hline
\end{tabular}


The study premise is based on identification of various competency principles, derivative of $21^{\text {st }}$ century skills (Abbot 2013; Dos Reis 2016; Morze, Makhachashvili, SmyrnovaTrybulska, 2016) for university staff members and projected digital literacy requirements. That way, a correspondence between $21^{\text {st }}$ century skills framework, Competences 2020 framework and the newly devised Global Skills framework (WEF, 2020) has been devised (Table 2):

Table 2.

$21^{\text {st }}$ century skills vs Competences 2020

\begin{tabular}{|c|c|c|}
\hline $21^{\text {st }}$ CENTURY SKILLS & COMPETENCES 2020 & GLOBAL SKILLS \\
\hline $\begin{array}{l}\text { CRITICAL THINKING AND PROBLEM } \\
\text { SOLVING }\end{array}$ & $\begin{array}{l}\text { COMPLEX PROBLEM SOLVING } \\
\text { CRITICAL THINKING } \\
\text { ARGUMENTATION AND } \\
\text { DECISION MAKING }\end{array}$ & $\begin{array}{l}\text { CRITICAL THINKING AND } \\
\text { ANALYSIS }\end{array}$ \\
\hline $\begin{array}{l}\text { LEARNING AND INNOVATION SKILLS } \\
\text { FLEXBILITY AND ADAPTABILITY } \\
\text { ICT-LITERACY }\end{array}$ & $\begin{array}{l}\text { COGNITIVE FLEXIBILITY } \\
\text { CREATIVITY }\end{array}$ & $\begin{array}{l}\text { CREATIVITY, ORIGINALITY } \\
\text { AND INITIATIVE } \\
\text { ACTIVE LEARNING AND } \\
\text { LEARNING STRATEGIES }\end{array}$ \\
\hline $\begin{array}{l}\text { COMMUNICATION/COLLABORATION } \\
\text { SKILLS }\end{array}$ & $\begin{array}{l}\text { INTEGRATION } \\
\text { NEGOTIATION } \\
\text { TEAMWORK }\end{array}$ & $\begin{array}{l}\text { LEADERSHIP AND SOCIAL } \\
\text { INFLUENCE } \\
\text { COORDINATION AND TIME } \\
\text { MANAGEMENT }\end{array}$ \\
\hline INITIATIVE AND DRIVE & $\begin{array}{l}\text { EMOTIOANL INTELLECT } \\
\text { HUMAN RESOURCES } \\
\text { MANAGEMENT }\end{array}$ & $\begin{array}{l}\text { ATTENTION TO DETAIL, } \\
\text { TRUSTWORTHINESS } \\
\text { SELF-MANAGEMENT }\end{array}$ \\
\hline $\begin{array}{l}\text { SOCIAL SKILLS AND CROSS- } \\
\text { CULTURAL SKILLS }\end{array}$ & $\begin{array}{l}\text { EMOTIONAL INTELLECT } \\
\text { SERVICE ORIENTATION }\end{array}$ & $\begin{array}{l}\text { EMOTIONAL INTELLIGENCE } \\
\text { COORDINATION AND TIME } \\
\text { MANAGEMENT } \\
\text { REASONING AND IDEATION }\end{array}$ \\
\hline
\end{tabular}

A unified framework of correspondence between the crucial communicative competence (Hymes, 1972) and various aspects of ICT competence in Liberal Arts (Ecompetences, 2020), utilized in the educational process, has been elaborated for the purposes of this study (Table 3):

Table 3.

Correspondence between communicative competence and ICT competence in Liberal Arts

\begin{tabular}{|l|l|c|}
\hline $\begin{array}{c}\text { Communicative } \\
\text { competence } \\
\text { components }\end{array}$ & \multicolumn{1}{|c|}{ Disambiguation } & $\begin{array}{c}\text { ICT competence } \\
\text { components } \\
\text { correspondence in } \\
\text { Liberal Arts }\end{array}$ \\
\hline $\begin{array}{l}\text { Linguistic } \\
\text { competence }\end{array}$ & $\begin{array}{l}\text { the knowledge of the language code, i.e. its grammar and vocabulary, } \\
\text { and also of the conventions of its written representation (script and } \\
\text { orthography). The grammar component includes the knowledge of the } \\
\text { sounds and their pronunciation (i.e. phonetics), the rules that govern } \\
\text { sound interactions and patterns (i.e. phonology), the formation of } \\
\text { words by means of e.g. inflection and derivation (i.e. morphology), the } \\
\text { rules that govern the combination of words and phrases to structure } \\
\text { sentences (i.e. syntax), and the way that meaning is conveyed through } \\
\text { language (i.e. semantics). }\end{array}$ & $\begin{array}{l}\text { Partion in } \\
\text { initiatives of regional and } \\
\text { national levels }\end{array}$ \\
\hline
\end{tabular}




\begin{tabular}{|c|c|c|}
\hline $\begin{array}{l}\text { Sociolinguistic } \\
\text { competence }\end{array}$ & $\begin{array}{l}\text { knowledge of sociocultural rules of use, i.e. knowing how to use and } \\
\text { respond to language appropriately. The appropriateness depends on } \\
\text { the setting of the communication, the topic, and the relationships } \\
\text { among the people communicating. Moreover, being appropriate } \\
\text { depends on knowing what the taboos of the other culture are, what } \\
\text { politeness indices are used in each case, what the politically correct } \\
\text { term would be for something, how a specific attitude (authority, } \\
\text { friendliness, courtesy, irony etc.) is expressed etc. }\end{array}$ & $\begin{array}{l}\text { Creating } \\
\text { courses/tasks }\end{array}$ \\
\hline $\begin{array}{l}\text { Discourse } \\
\text { competence }\end{array}$ & $\begin{array}{l}\text { knowledge of how to produce and comprehend oral or written texts in } \\
\text { the modes of speaking/writing and listening/reading respectively. It's } \\
\text { knowing how to combine language structures into a cohesive and } \\
\text { coherent oral or written text of different types. Thus, discourse } \\
\text { competence deals with organizing words, phrases and sentences in } \\
\text { order to create conversations, speeches, poetry, email messages, } \\
\text { newspaper articles etc. }\end{array}$ & System using of ICT \\
\hline $\begin{array}{l}\text { Strategic } \\
\text { competence }\end{array}$ & $\begin{array}{l}\text { ability to recognize and repair communication breakdowns before, } \\
\text { during, or after they occur. For instance, the speaker may not know a } \\
\text { certain word, thus will plan to either paraphrase, or ask what that word } \\
\text { is in the target language. During the conversation, background noise } \\
\text { or other factors may hinder communication; thus the speaker must } \\
\text { know how to keep the communication channel open. If the } \\
\text { communication was unsuccessful due to external factors (such as } \\
\text { interruptions), or due to the message being misunderstood, the speaker } \\
\text { must know how to restore communication. These strategies may be } \\
\text { requests for repetition, clarification, slower speech, or the usage of } \\
\text { gestures, taking turns in conversation etc. }\end{array}$ & $\begin{array}{l}\text { Presentation to the } \\
\text { community the results of } \\
\text { their own research } \\
\text { activity through the use } \\
\text { of ICT }\end{array}$ \\
\hline
\end{tabular}

The following study aims to identify, among other parameters, challenges for actual and underdeveloped skills (hard, technical and soft), that participants of the educational process encountered through Final Qualification Assessment in programs of European and Oriental Languages.

Legal Basis and Profile of Final Qualification Assessment as an Education Activity. Qualification assessment for Foreign Languages major programs in particular is a strict regimen process that involves different stages (oral and written exams, final project viva, internal and external review).

According to the Law of Ukraine "On Higher Education" (Zakon, 2019), qualification assessment is the establishment in compliance of learning outcomes (scientific or creative work) of higher education students with the requirements of the educational (scientific, educational and creative) program and / or the single state qualifying exam.

The form of state certification of students is defined by the state standards of education and is reflected in the curricula of the Free Economic Zone. Usually state certification has two forms:

1) State exam;

2) Defense (viva) of qualification (bachelor's) paper.

State standards of education provide for the existence and observance of rules and requirements for the procedure of state certification. In addition, the defense of the qualification work contains propaedeutic procedures designed to obtain the basis for admission of students to the defense.

Passing of state examinations and defense of qualifying works is carried out at an open meeting of the SEC with the participation of members of the commission and the obligatory presence of the chairman of the commission. The work of SEC is carried out in the terms provided by the schedule of educational process. The state exam takes place at the approved time and in the audience specified in the documentation of preparation for the SEC. 
The last link in the learning process is the defense of the thesis (project). This type of activity is characterized by the completion of the entire educational process and the assignment of appropriate qualifications to the student.

The supervisor should provide feedback on the work of his / her graduate, assessing all theoretical and practical aspects of the work with a probable grade, subject to successful defense. In addition to the response of the head, the work is accompanied by an external review by a scientist from the teaching staff, who works in the institutions of the Free Economic Zone of Ukraine and is a specialist in the subject of the diploma. In addition to assessing all aspects of the work, the external reviewer has the right to ask (record in the review form) his question to the student. The chairman or members of the committee must read the student's questions from the reviewer.

The student is given 5-8 minutes to defend his thesis. After defending his work, accompanied by a presentation on a multimedia projector, the chairman of the commission and members of the commission ask students questions related to the theoretical and practical aspects of the diploma work. After receiving the answers read (if any) questions from an external reviewer. After the student answers all the questions, the chairman of the commission reads the response of the supervisor and the external review.

After the thesis has been defended by the last student on the list, the results of the defense should be discussed. The commission discusses the results in the same auditorium where the defense took place, with the participation of only the chairman of the commission, its members and the secretary of the SEC.

In the situation of the COVID-19 pandemic lockdown all elements of the Final Qualification Assessment at Borys Grinchenko Kyiv University for European and Oriental Languages programs have been relegated to the digital, remote or blended format with the use of ICT tools.

The qualification assessment regimen was adapted to digital format as a framework (a legal procedure that results in the degree confirmation of a student), the string of consecutive activities according to the legal procedure described in the profile above, the "ritual" scenario (and experience for the student that is emotionally uplifting and somber in nature, connects with the traditions of the university culture of Europe).

According to the law mandated Qualification Assessment activities for foreign languages at Borys Grinchenko Kyiv university have been transferred to digital remote format in the following manner (Table 4):

Table 4.

Qualification Assessment activities for European and Oriental languages at Borys Grinchenko Kyiv university transfer to digital remote format

\begin{tabular}{|l|l|l|}
\hline \multicolumn{1}{|c|}{$\begin{array}{l}\text { QUALIFICATION ASSESSMENT } \\
\text { ACTIVITIES }\end{array}$} & DIGITAL REMOTE ANALOGY & \multicolumn{1}{|c|}{ SAMPLE ICT TOOLS } \\
\hline $\begin{array}{l}\text { State exam conduct (introduction, oral } \\
\text { answers, grading, } \\
\text { discussion, results) }\end{array}$ & $\begin{array}{l}\text { Digital video conference; } \\
\text { Remote test } \\
\text { Video recording } \\
\text { Voice recording }\end{array}$ & $\begin{array}{l}\text { Conference service (Zoom, Webex, } \\
\text { GoogleMeet) } \\
\text { Speech converter (Speech Texter) } \\
\text { LMS (Moodle, Google Classroom) } \\
\text { Webcam }\end{array}$ \\
\hline State Exam card selection & Digital randomizing & \\
\hline & & $\begin{array}{l}\text { LMS Moodle test resource, } \\
\text { Google randomizer }\end{array}$ \\
State Exam discussion and questions & Digital video conference; & $\begin{array}{l}\text { Conference service (Zoom, Webex, } \\
\text { GoogleMeet) } \\
\text { Social media (Department site on } \\
\text { Faceboook) messenger } \\
\text { Mobile } \\
\text { (WhatsApp, Telegram) }\end{array}$ \\
\end{tabular}




\begin{tabular}{|c|c|c|}
\hline & $\begin{array}{l}\text { Chat service; } \\
\text { Mobile connection }\end{array}$ & \\
\hline State Exam assessment & $\begin{array}{l}\text { Digital video conference; } \\
\text { Automated grading system; } \\
\text { Online/offline calculator } \\
\end{array}$ & $\begin{array}{l}\text { Conference service (Zoom, Webex, } \\
\text { GoogleMeet) } \\
\text { LMS (Moodle, Google Classroom) } \\
\text { Google Suite } \\
\text { MS Excel }\end{array}$ \\
\hline State Exam results declaration and appeal & $\begin{array}{l}\text { Digital video conference } \\
\text { Cloud services }\end{array}$ & $\begin{array}{l}\text { Conference service (Zoom, Webex, } \\
\text { GoogleMeet) } \\
\text { Google Suite (Google disc, Google } \\
\text { Tables, e-mail) }\end{array}$ \\
\hline Bachelor's project viva/defense & $\begin{array}{l}\text { Digital video conference } \\
\text { Screen sharing } \\
\text { File sharing } \\
\text { Video recording } \\
\text { Voice recording } \\
\end{array}$ & $\begin{array}{l}\text { Conference service (Zoom, Webex, } \\
\text { GoogleMeet), Google Suite (Google } \\
\text { disc), MS Office Toolkit } \\
\text { (PowerPoint), Microsoft Power Pint, } \\
\text { Cloud presentation tools (Prezi), } \\
\text { Cloud Apps (Sketch Engine), Social } \\
\text { media }\end{array}$ \\
\hline $\begin{array}{l}\text { Bachelor's project viva/defense publicity and } \\
\text { accessibility }\end{array}$ & Public announcement via digital media & $\begin{array}{l}\text { Google Suite (E-mail, Google Disk) } \\
\text { Android Apps (messenger services) } \\
\text { Social media (Department site on } \\
\text { Facebook, Instagram, Twitter) }\end{array}$ \\
\hline Bachelor's project submission & File sharing & Google Suite (Google Disk, e-mail) \\
\hline Bachelor's project review & $\begin{array}{l}\text { Digital survey } \\
\text { Digital assessment }\end{array}$ & $\begin{array}{l}\text { Google Suite (Google Forms, Google } \\
\text { Excel), MS Office Toolkit } \\
\text { (Microsoft Excel, MS Word) }\end{array}$ \\
\hline Bachelor's project discussion and questions & $\begin{array}{l}\text { Digital video conference; } \\
\text { Chat service; } \\
\text { Mobile connection }\end{array}$ & $\begin{array}{l}\text { Conference service (Zoom, Webex, } \\
\text { GoogleMeet) } \\
\text { Social media (Department } \\
\text { Facebook) } \\
\text { Mobile messenger } \\
\text { (WhatsApp, Telegram) }\end{array}$ \\
\hline Bachelor's project assessment & $\begin{array}{l}\text { Digital video conference; } \\
\text { Automated grading system; } \\
\text { Online/offline calculator }\end{array}$ & $\begin{array}{l}\text { Conference service (Zoom, } \\
\text { Webex, GoogleMeet), LMS, Google } \\
\text { Suite, MS Toolkit }\end{array}$ \\
\hline $\begin{array}{l}\text { Bachelor's project results declaration and } \\
\text { appeal }\end{array}$ & $\begin{array}{l}\text { Digital video conference } \\
\text { Cloud services }\end{array}$ & $\begin{array}{r}\text { Conference service (Zoom, } \\
\text { Webex, GoogleMeet), Google Suite } \\
\text { (Google disc, Google Tables, e-mail) }\end{array}$ \\
\hline
\end{tabular}

The comprehensive transference process of the Final Qualification Assessment procedure for European and Oriental languages programs from face-to-face into all-digital format was accompanied by the following common challenges:

1) Normative documentation format adaptation (the issue of born digital documentation): 
- Bachelor's thesis format conversion from manuscript to a secure digital document;

- Digital signatures format adaptation for manuscript authenticity confirmation (the combination of scanned hand-written confirmation and digital signature seal);

- Scrapping of a narrative review format in favor of the rubricated automated assessment of the thesis/project via authenticated digital forms (the issue exposed a challenge of a more rigorous review procedure and less lee-way);

- Identification procedure adaptation from an audio-visual roll-call to verified picture ID screenshots (the issue called for a different timeframe set-up in the assessment procedure, extra pressure on the participants);

- Documentation publicity (theses digitized manuscripts, reviews, assessment spreadsheets) via file-sharing which brought on extra exposure for peer-to-peer assessment.

2) The need for digital literacy boot camp for all participants of the Final Qualification Assessment process for all stages of the procedure:

- Discrepancies in the use of different conference platforms in different universities (which put invited experts at an initial disadvantage);

- Lack of proficiency in the use of LMS tools for specific purposes (tests, test results export, essay question randomizer);

- Lack of proficiency in use of specific conference service interface options (for e.g. screen sharing, separate rooms division, individual and public chats);

- Lack of proficiency in use of Google Suite tools (especially thesis review options via Google Forms);

- Lack of proficiency in the use of mobile versions and Android/iOS app versions of platforms, tools and services, used in Final Qualification Assessment process;

3) Digital divide in accessibility of computer and Web technologies, necessary for all stages of Final Qualification Assessment procedure:

- Internet bandwidth and stability of connection;

- Update of PC hardware and software for all participants of the Final Qualification Assessment process (out of date software impaired videoconferencing possibilities, for e.g.);

- Access to back-up smart devices to carry out the Final Qualification Assessment procedure.

4) Soft skills and emotional challenges:

- Time-management

- Self-management under duress;

- Collaboration and networking via digital media in the lockdown framework;

- Emotional intelligence and awareness;

- Critical thinking and decision making;

- Learning and innovation (professional activity outside of the comfort zone).

Digital Skills and ICT Tools for Final Qualification Assessment in the Framework of COVID-19: survey study. The Final Qualification assessment activity profile, digital format adaptation and listed accompanying challenges, that were detected, informed the survey among the participants of the Final Qualification Assessment at Borys Grinchenko Kyiv University foreign languages programs (Spanish, French, Italian, English, Mandarin Chinese, Japanese major). The survey was conducted over the span of late June-early July of 2020, right after the wrap up of all Qualification Assessment procedures. The survey comprised of 12 
questions (multiple choice, scoring and scaling types), crafted to assess the efficiency of qualification assessment transfer into digital format via various ICT tools employed.

The following participants of the digital Final Qualification Assessment were respondents of the survey:

- Students of senior year of bachelor's program;

- Assessment board members;

- Faculty members (who took part in digital qualification assessment preparation and conduct);

- Bachelor project referees and supervisors.

Respondents of all groups took part in the survey (Figure 2) - 59 total. The choice of respondent groups corresponded to the variation or similarity of tasks, performed throughout Final Qualification Assessment by representatives of European and Oriental languages programs and, subsequently, the variation and similarity of ICT tools used.
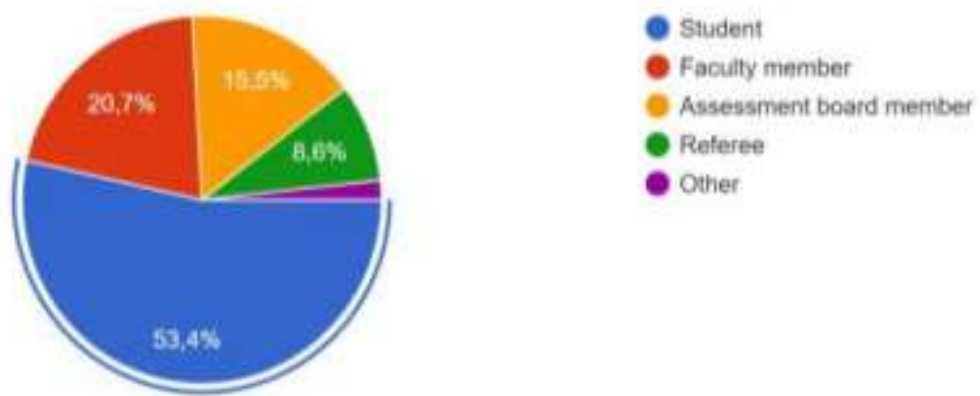

Fig. 2. Respondent status in digital qualification assessment. Source: Own research

Respondents of all groups spanned the foreign language Bachelor's programs in proportional distribution measures:

- $\quad$ Spanish major program- 32,8\%

- Japanese major program- 19\%

- $\quad$ Mandarin Chinese major program - 22,4\%

- $\quad$ French major program - 15,5\%

- $\quad$ Italian major program- $15,5 \%$

- $\quad$ English major program- 8,6\%.

The overall digital qualification assessment experience on the scale of 1 to 5 was defined as mostly agreeable (4) by $50 \%$ of respondents, most agreeable (5) by $29 \%$ of respondents and less agreeable (3) by $17 \%$ of respondents. It's worth noting that the digital activities got overall rankings of 5-4 from respondents of European languages programs and 4-2 from respondents of Oriental languages programs.

The respondents identified all the ICT digital tools that they have to employ the most in digital qualification assessment process (Figure 3). The highest scoring ICT tools by all the groups of respondents of both European and Oriental language programs were:

- e-mail (93\% of respondents),

- Google services (76\% of respondents),

- videoconferencing services (84\% of respondents),

- $\quad$ social media platforms (77\% of respondents),

- automated testing systems and learning management systems (31\% of respondents). 


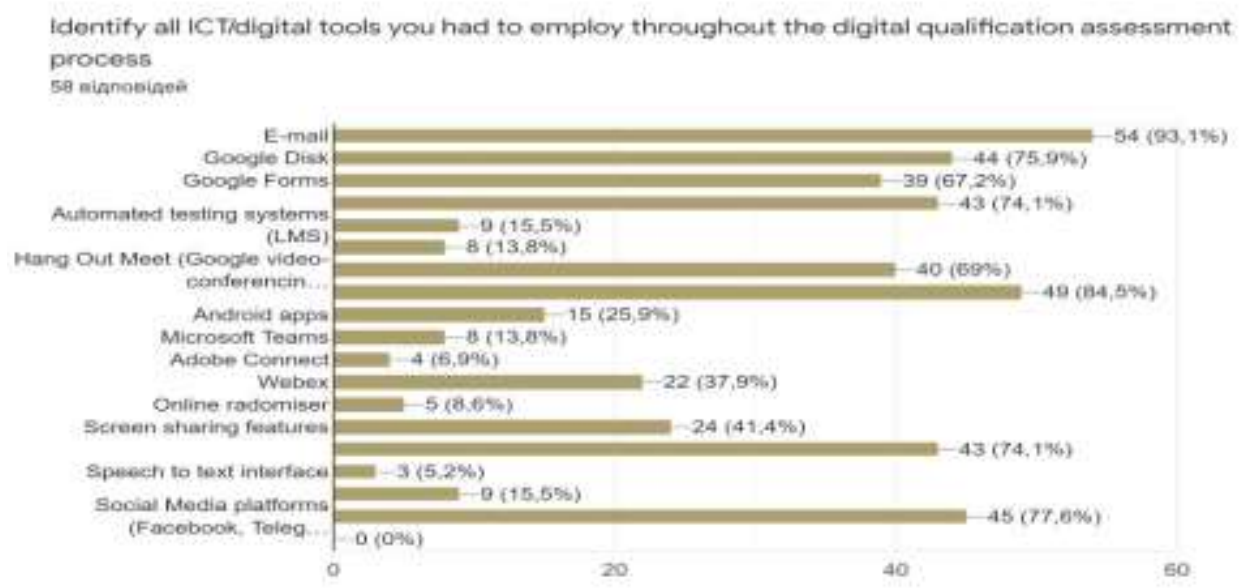

Fig. 3. ICT tools identification through the digital qualification assessment. Sample evaluation card Source: Own research

The ranking 1-5 of the ICT tools employed through digital qualification assessment process yields following tools getting the highest scoring (5) among all ICT tools identified and used: email services; google forms; Zoom video conferencing services; screen sharing services; Microsoft Office tool-kit and various social media platforms.

The respondents identified the following most prominent activities across all ICT tools used throughout the digital qualification assessment process $t$ (Figure 4):

- Communication (synchronous)

- Communication (asynchronous)

- Collaboration

- Information/file sharing

- Summative assessment

- Formative assessment

- Peer review

- Presentation

- $\quad$ Speech quality assessment

- $\quad$ Brainstorming

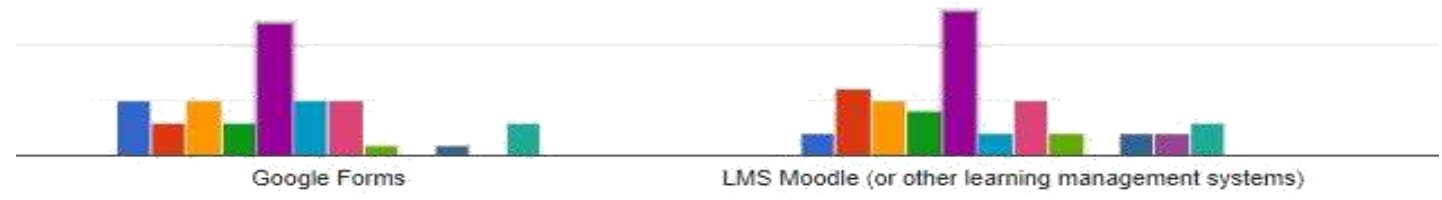

Fig. 4. ICT tools used throughout the digital qualification assessment. Sample evaluation card Source: Own research

Information sharing and presentation are considered prominent for such types of tools as email, Google services, Microsoft Office Toolkit.

Both synchronous and asynchronous communication and collaboration is distributed proportionally among email services, learning management systems and various video conference services. 
The tools that feature summative assessment as a prominent activity are Google forms and LMS Moodle.

Formative assessment as a type of activity features but does not dominate evaluation of ICT tools used qualification assessment process.

The following technical and user requirements, most prominent for ICT/digital tools employed throughout the digital qualification assessment process were identified (Figure 5):

- Bandwidth

- $\quad$ Specialized software

- $\quad$ Specialized hardware (webcam, mic, PC type etc.)

- Intuitive interface

- $\quad$ Advanced digital literacy

- Intermediate digital literacy

- Elementary digital literacy

- $\quad$ Customized training before use

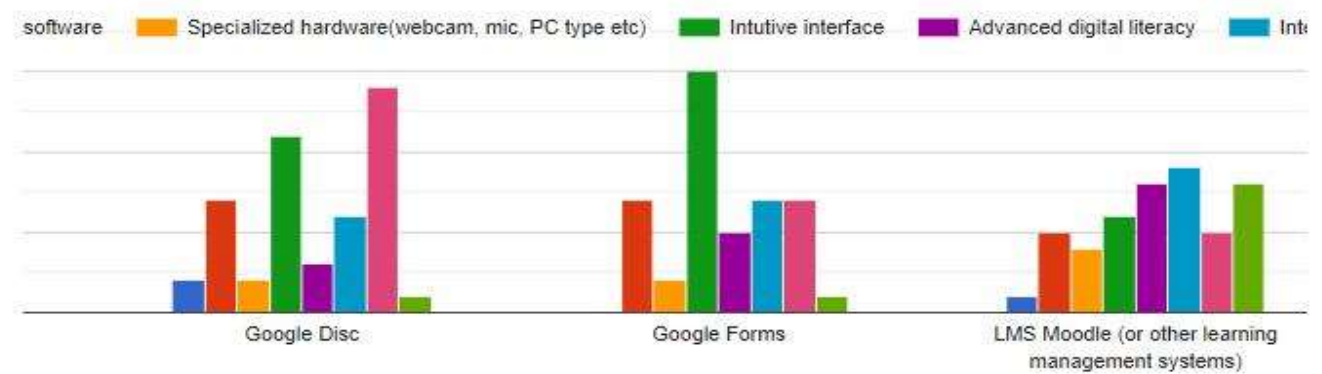

Fig. 5. Technical and user requirements, for ICT tools digital qualification assessment process. Sample evaluation card Source: Own research

Intuitive interface is a technical requirement to future the most across the board of ICT digital tools that have been analyzed. It is considered a leading technical requirement for such ICT tools as email, Google services, video conferencing services and social Media platforms.

Specialized software as a requirement is mandatory and ranking second for such tools as email and Google services.

The only tool employed in qualification assessment customized training before use as a prominent requirement by respondent is the LMS Moodle platform.

Respondents of the European languages program have assessed the prominent ICT tools requirements (Figure 6 ) being Intuitive interface $(28,8 \%)$, elementary digital literacy $(26,9)$ and specialized software $(17,3 \%)$.

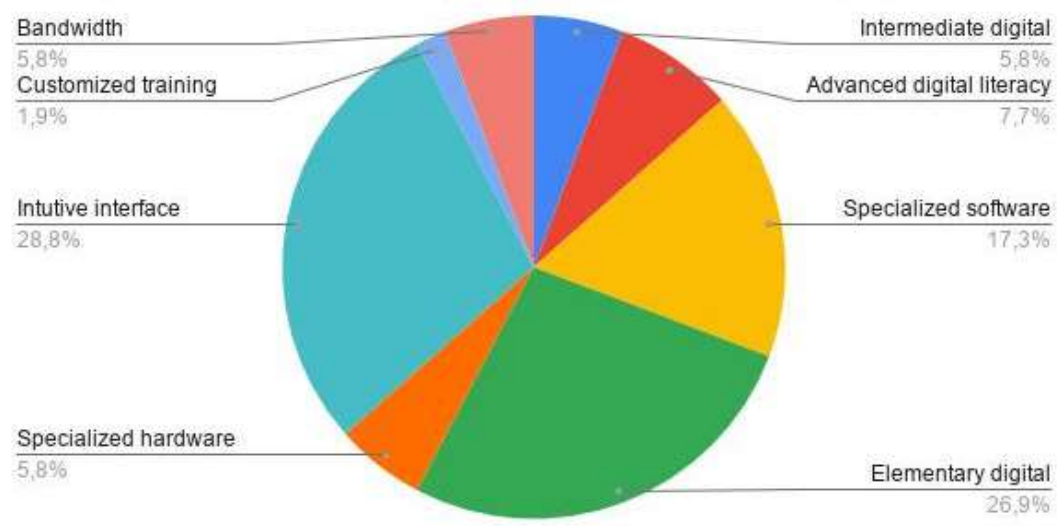

Fig. 6. Technical and user requirements, for ICT tools digital qualification assessment process for European languages program. Sample evaluation card

Source: Own research 
Respondents of the Oriental languages program have assessed the prominent ICT tools requirements (Figure 7 ) being Intuitive interface $(31,8 \%)$, elementary digital literacy $(31,8)$ and bandwidth and advanced digital literacy $(9,1)$.

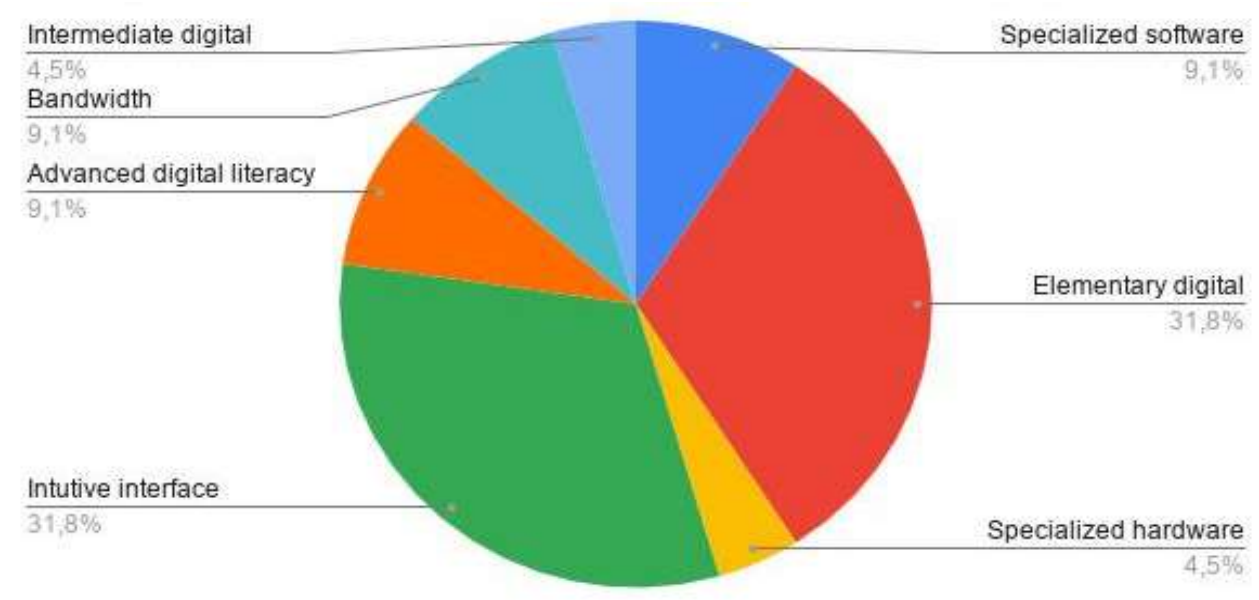

Fig. 7. Technical and user requirements, for ICT tools digital qualification assessment process for Oriental languages program. Sample evaluation card Source: Own research

Various levels of digital literacy have been identified in the survey. Digital literacy is understood primarily as the ability to use information and communication technologies to find, evaluate, create, and communicate information, requiring both cognitive and technical skills (ALA, 2020; DQ Report, 2019).

Advanced digital literacy as the requirement for qualification assessment ICT tools efficiency is attributed to such instruments as learning management systems, Microsoft Office toolkit and social media platforms.

Intermediate digital literacy is required predominantly for such instruments as Microsoft Office Toolkit, screen sharing interface, online randomizer, automated testing system, learning management system.

Elementary digital literacy level is assessed as dominant for such tools as email, google disc, video conferencing, speech to text interfaces and social media platforms.

Across various ICT tools for the digital qualification assessment process the following skills and competences most widely implemented and practiced, drawn from various relevant

$21^{\text {st }}$ century skills frameworks have been identified (Figure 8):

- Communication;

- Collaboration

- Team work

- Digital literacy

- Emotional intellect

- Interdisciplinary skills

- Critical thinking

- Leadership

- Flexibility and Adaptability

- Decision making

- Learning and Innovation skills 
Different priorities in soft skills are identified for participants of digital Qualification assessment of the European languages program (Figure 9) and Oriental languages program (Figure 10):

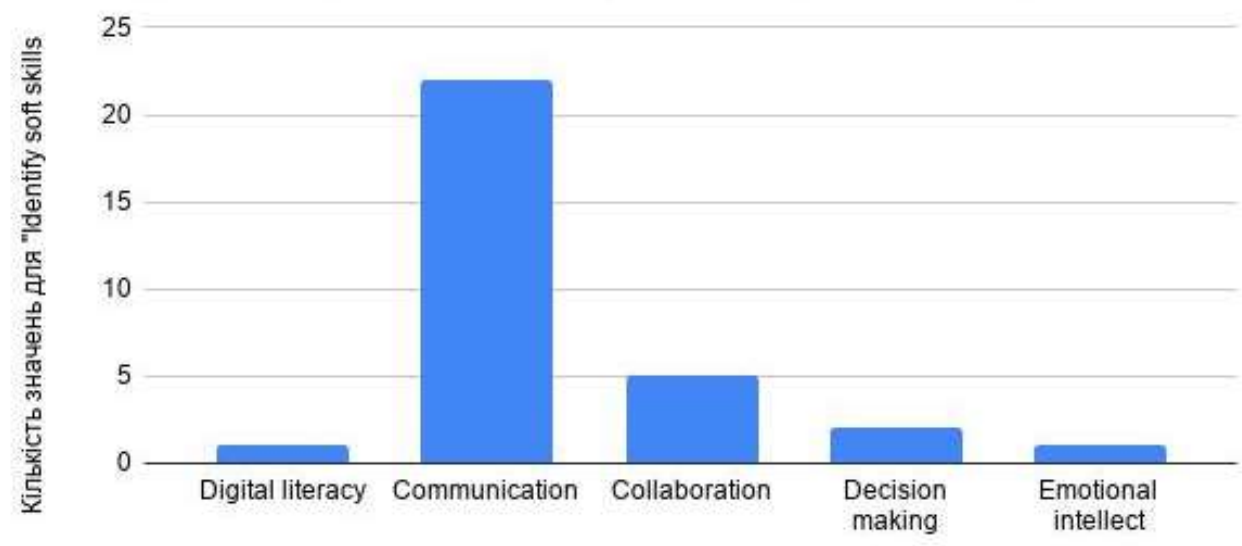

Identify soft skills most prominent for ICT/digital tools you had to employ throughout the digital

Fig. 9. Soft skills for ICT/digital tools in digital qualification assessment process for European languages program. Sample evaluation card.

Source: Own research

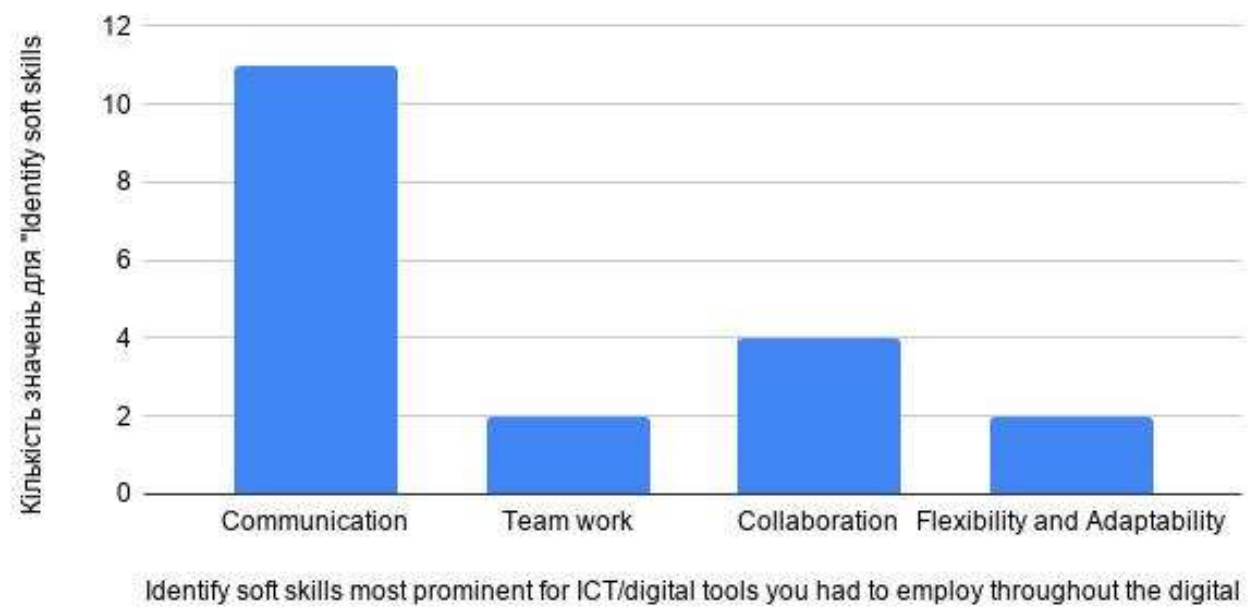

Fig. 10. Soft skills for ICT/digital tools in digital qualification assessment process for European languages program. Sample evaluation card.

Source: Own research

Communication and collaboration rank as a type of skills most widely applied for the use of such instruments as email, Google services, video conferencing services and social Media platforms. Communication as a skill is ranked highest among respondents of the European languages program.

Team work ranks second most prominent skill employed via the use of Google disk, learning management systems and video conferencing services. Team work and flexibility feature as top 5 priority skills among respondents of the Oriental languages program.

Relevance is attributed to learning and Innovation skills in the use of such ICT tools as a learning management system (ranking second after interdisciplinary skills), automated Testing System (offline, online and cloud based), Android apps and Microsoft Office tools. 
Creativity as a skill ranks 3rd in the use of Google services and ranks 1st in the use of Microsoft Office tools.

Conclusion. All procedures and scenarios of the Final Qualification Assessment activities for foreign languages at Borys Grinchenko Kyiv university have been successfully transferred to digital remote format with the use of various sets of ICT tools in the framework of the COVID-19 pandemic adjustments. This transference could serve as a best practice model for other universities of Ukraine and European countries both as an adaptable measure for prolonged lockdown and as a way to further advance of blended learning and further digitalization and democratization of educational process.

The survey results conducted among all groups of participants of Final Qualification Assessment for European and Oriental foreign languages have yielded representative data as to the efficiency of various ICT tools implementation for rigorous assessment procedure scenario. Microsoft Office toolkit ranks highest in efficiency among respondents, presumably, due to the least digital literacy level adjustments required of users at a short notice to carry out the full spectrum of necessary activities for Final Qualification Assessment.

Various levels of digital literacy have been identified in the survey. Across the board, implementation of Final Qualification Assessment via various ICT tools requires of participants of educational process elementary to intermediate digital literacy. There's no significant discrepancy in digital literacy and ICT competence requirements between Final Qualification Assessment participants of European and Oriental languages program.

Communication, collaboration and team work are evaluated as crucial soft skills in various combinations within the scenario of digital Final Qualification Assessment. This results corroborate the correspondence between communicative competence and ICT competence components, adapted for Liberal Arts. Namely, the following components prove indispensable for all participants of Final Qualification Assessment in digital format: participation in group ICT initiatives, creating e-learning tasks, system using of ICT, presentation to the community the results of one's own research activities through the use of ICT.

The survey results will be furthered and elaborated in assessment of ICT tools efficiency and digital skills adaptability for separate groups of Final Qualification Assessment (students of foreign languages programs, Assessment board members, staff members, reviewers) according to roles and tasks performed, as well as according to age and entry digital literacy level (the distinction in efficiency assessment among digital natives and digital immigrants). The perspective of the study is in corresponding survey of digital qualification assessment experiences of students and faculty members of Asian (Oriental) countries and countries of Europe.

Acknowledgements. The research methodology leading to these results was elaborated within the framework of the IRNet project, funding from the People Programme (Marie Curie Actions) of the European Union's Seventh Framework Programme FP7/2007-2013/ under REA grant agreement No: PIRSES-GA-2013- 612536. Empirical findings and survey procedures have been conducted under the auspices of Integrated Research framework of Romance Languages and Typology Chair of Borys Grinchenko Kyiv University European languages and literatures development in cross-communication context (0116 U 006607) and Integrated Research framework of Oriental Languages and Translation Chair of Borys Grinchenko Kyiv University Oriental Studies development in the framework of Higher Education Internationalization (0116U007073).

\section{REFERENCES}

Abbott, S. (Ed.) (2013). The glossary of education reform. July 17, 2020.

http://edglossary.org/hidden-curriculum.

American Library Association (2020). July 17, 2020.

https://literacy.ala.org/digital-literacy 
Davies, A., Fidler, D. et al (2011). Future Work Skills 2020. Institute for the Future for University of Phoenix Research Institute. October 10, 2020. https://www.iftf.org/uploads/media/SR-1382A_UPRI_future_work_skills_sm.pdf

Dos Reis A. (2016). ToBe a (Blended)Teacher in the 21st Century Some Reflections. Wydawnictwo Uniwersytetu Śląskiego.

Dos Reis A. (2017). Digital storytelling and technologies. Open educational eenvironment of modern University, No 3.

Eduventures in TechLandscape (2020). July 10, 2020.

https://encoura.org/2020-eduventures-tech-landscape-heres-what-to-expect/

European e-competence framework guideline (2020). July 10, 2020. https://www.ecompetences.eu/

Hymes, Dell H. (1972). Communicative competence: In Pride, J.B.; Holmes, J. Sociolinguistics: selected readings. Harmondsworth: Penguin. pp. 269-293.

Law "On Higher Education" (2019). July 11, 2020. https://zakon.rada.gov.ua/laws/show/1556-18\#Text

Morze N., Makhachashvili R. \& Smyrnova-Trybulska E. (2016). Communication in education: ICT tools assessment. Proceedings from DIVAI, 351-354.

Morze, N., Makhachashvili, R. \& Smyrnova-Trybulska, E. (2016) Research in Education: Survey Study. ICTE 2016 - Information and Communication Technologies in Education., 114-123. July 11, 2020.

https://unesdoc.unesco.org/ark:/48223/pf0000265721

Taleb, N. (2010). The Black Swan: the impact of the highly improbable (2nd ed.). London: Penguin. ISBN 978-0-14103459-1.

World Economic Forum (2020). The Future of Jobs Report. October 10, 2020. http://www3.weforum.org/docs/WEF_Future_of_Jobs_2020.pdf

World's first global standard for digital literacy, skills and readiness launched by the Coalition for Digital Intelligence (2019). The DQ Global Standards Report. July 11, 2020. https://www.dqinstitute.org/ (accessed July 2020).

\title{
РОЗВИТОК ЦИФРОВИХ НАВИЧОК ТА ІКТ ІНСТРУМЕНТИ ДЛЯ ПІДСУМКОВОЇ КВАЛІФЦЦЙНОЇ АТЕСТАЦЇ̈: ДОСЛІДЖЕННЯ РЕЗУЛЬТАТІВ ОПИТУВАННЯ СТУДЕНТІВ ТА ВИКЛАДАЧІВ ПРОГРАМ 3 ЄВРОПЕЙСЬКОЇ ТА СХІДНОЇ ФІЛОЛОГІї
}

\author{
Махачашвілі Русудан Кирилевна \\ Доктор філологічних наук, доцент, завідувач кафедри романської філології \\ та порівняльно-типологічного мовознавства \\ Київський університет імені Бориса Грінченка, Київ, Україна \\ r.makhachashvili@kubg.edu.ua \\ ORCID: 0000-0002-4806-6434
}

\section{Семеніст Іван Васильович}

Кандидат історичних наук, завідувач кафедри східних мов та перекладу

Київський університет імені Бориса Грінченка, Київ, Україна

i.semenist@kubg.edu.ua

ORCID 0000-0002-0847-8856

\section{Бахтіна Анна Олегівна}

Викладач, аспірант кафедри романської філології

та порівняльно-типологічного мовознавства

Київський університет імені Бориса Грінченка, Київ, Україна

a.bakhtina@kubg.edu.ua

ORCID: 0000-0003-3337-6648 
Анотація. Глобальна пандемия та карантинні заходи й обмеження створили низку викликів структурі та процедурі підсумкового оцінювання в університетах. Кваліфікаційне оцінювання випускників програм з іноземних мов, зокрема, $є$ регламентованою процедурою, яка включає різні етапи (усні та письмові іспити, підсумковий проект, внутрішнє та зовнішнє рецензування). Розглянуто фактори соціальних змін, що забезпечують критичну трансформацію набору навичок, що є вирішальним для надзвичайної освітньої ситуації в умовах Ковід-19. Передумова дослідження базується на виявленні різних рамок компетентностей, похідних від навичок 21 століття, для співробітників університетів та прогнозованих вимог до цифрової грамотності. Розроблено відповідність між структурою навичок 21 століття, структурою компетенцій 2020 та системою глобальних навичок. Метою дослідження є критичний огляд прикладного куйсу та передового досвіду цифрового підсумкового кваліфікаційного оцінювання в Київському університеті імені Бориса Грінченка для студентів освітніх програм з європейських (французька, італійська, іспанська, англійська, німецька) та східних (китайська, японська) мов у 2020 році, в умовах карантинних обмежень. Опитування та аналіз різних ІКТ-інструментів використовується для трансляції практик кваліфікаційного оцінювання в реальному житті у змішаний форматта електронний формат. Дослідження також має за мету виявити різні групи прикладних цифрових навичок та навичок співпраці, які використовуються в процесі кваліфікаційного оцінювання усіма учасниками (студентами, викладачами та рецензентами). Визначено, як у ситуації карантинних обмежень Ковід-19 усі елементи Підсумкової кваліфікаційної атестації 3 європейських та східних мов в Київському університеті імені Бориса Грінченка були переведені у цифровий, віддалений або змішаний формат із використанням засобів ІКТ. Режим кваліфікаційного оцінювання для освітніх програм з іноземних мов був адаптований до цифрового формату яка рамковий контекст (юридична процедура, що призводить до підтвердження ступеня випускника), низка послідовних комунікативних заходів відповідно до юридичної процедури, "ритуальний" сценарій. Визначено порівняльні результати адаптації цифрового формату Підсумкової кваліфікаційної атестації для різних груп освітніх програм іноземних мов (європейських та східних).

Ключові слова: ІКТ інструменти та практики; Підсумкова кваліфікаційна атестація; цифрова грамотність; змішане навчання; метод опитування; європейські мови; східні мови 